\title{
ELVÁRT KÖVETELMÉNY-E AZ ÓVODAPEDAGÓGUSOKTÓL A BESZÉDMÚVELTSÉG?
}

\author{
Szerző: \\ H. Tóth István (Dr., CSc) \\ Univerzita Karlova (Csehország)
}

Szerző e-mail címe:

david228@freemail.hu

\author{
Lektorok: \\ Szőke Anna (PhD) \\ Szegedi Tudományegyetem \\ Ferenczyné Kerekes Edit \\ Angyelkert Óvoda, Kecskemét \\ ...és további két anonim lektor
}

\begin{abstract}
Absztrakt
E tanulmány az óvodapedagógusok beszédműveltségére és a kisgyermekek beszédének és ismereteinek fejlesztésére irányuló feladataikra összpontosít. A tanulmány konkrét példákat is ad az óvodai gyermekek beszédfejlesztéséhez.
\end{abstract}

Kulcsszavak: beszéd, beszédmúveltség, óvoda

Diszciplina: pedagógia

\begin{abstract}
Abstarct
IS THE SPEECH-LITERACY AN EXPECTABLE REQUIREMENT FROM KINDERGARTEN TEACHERS?

This study focuses on the speech literacy of kindergarten teachers and their tasks about to development of speech and knowledge of young children. The study also gives concrete examples in order to speech development of preschool children.
\end{abstract}

Keywords: speech, speech literacy, kindergarten

Discipline: pedagogy

H. Tóth István (2020): Elvárt követelmény-e az óvodapedagógusoktól a beszédműveltség? OxIPO - interdiszciplináris tudományos folyóirat, 2020/2, 65-84. doi: 10.35405/OXIPO.2020.2.65 


\section{Elöljáróban}

A címbeli kérdésre némi malíciával füszerezve ekképpen is válaszolhatok: „Tudja a fene!”. Mármint arra nézve, hogy létezik-e követelmény a pedagógusok beszédműveltségével kapcsolatban, vagy a helytelenül értelmezett szabadság okán itt is a szabadosság a mértékadó. A nem kevés nyugtalanító tapasztalatom késztetett az itt következő gondolataim kifejtésére. A kisgyermekkori nevelésre-gondozásra, különös tekintettel az óvodapedagógusok beszédműveltségére összpontosító mostani írásom kikristályosító mottója az osztrák polihisztor, filozófus, a Waldorfpedagógia megalkotója, Rudolf Steiner életművéből hangzik ekképpen: „Az egész gyermek olyan, mint egyetlen érzékszerv: minden hatásra reagál, amit emberek váltanak ki belőle. Hogy egész élete egészséges lesz-e vagy sem, attól függ, hogyan viselkednek a közelében." (megjegyzés: az antro-pozófia az emberre vonatkozó, illetőleg az emberből kiinduló bölcsesség és tudás, vagyisaz ember megismerésének bölcsészeti alapelvekre épülő tana). Nem lehet vita közöttünk arról, hogy pontos látlelet ez a gondolat, ebből adódóan jelentős hatásfokú útravaló a kisgyermekkori nevelőknek.

\section{Célkitűzésül}

Jelen tanulmányban úgy szólok a kisgyermekkori neveléssel foglalkozók beszédműveltségének bizonyos kérdéseiről, hogy elsősorban a társadalmi szocializáció nyelvi, nyelvhasználati kérdésköreit érintem. Ennek az okait mindenekelőtt a társadalomban robbanásszerűen zajló, a kisgyermekek személyiségét drámaian befolyásoló tényezők adják (H. Tóth, 2020a). Lássunk néhányat ezek közül!

- Még érvényesül, de ki tudja, meddig, hogy általában húsz-harminc éves korú házasok kisgyermekei érkeznek az óvodai hálózat különböző típusú intézményeibe.

- Ugyanakkor világjelenséggé dagadt immár az a folyamat, miszerint anyagi és/vagy karrierépítési okok miatt később vállalnak gyermekáldást a nemző- és fogamzásképes felnőttek.

- Az európai gyökerű kultúrákban még tipikusnak tekinthetô továbbra is a nő és férfi házassága, az ebben a kapcsolatban születendő gyermekek reményteljes várása.

- Emellett a hagyományos családmodell mellett mindinkább terjedőben a nô és nő, a férfi és férfi házastársi kapcsolatában vállalt, örökbe fogadott gyermekek nevelése, gondozása.

- Azoknak a felnőtt korosztályoknak, amelyik korosztályoknak a tagjai, éljenek a társadalom bármelyik rétegében is, a kisgyermekei a mai idők óvodáiba érkeznek úgy, hogy a szüleik a világ információ- és technológiai robbanásának élvezői, illetőleg megélői, akik sms-, „fészbúk”-, „szkájp”-, blog-, twitter-típusú, jellegű, műfajú szó- és emotikonörvényekből szövegnek alig- 
alig nevezhető közleményekkel, közleményekben kommunikálnak. Ugye, elképzelhető, hogy milyen minőségű azoknak a népeknek a kapcsolatteremtése, kapcsolatmúködtetése, vagyis kommunikációja, sőt vitakultúrája, társalgásetikettje, akik így vesznek részt a társadalmi együttélésben?

\section{Kiindulópontok}

Jelentős ideje bizonyított tudásunk, miszerint kiemelten fontos a társadalomba fejlődésünk, a társadalomba érésünk, vagyis emberré válásunk szempontjából, hogy milyen gazdasági és szociális hátterű családba születünk bele. Mindkét alapvetés szerves kapcsolatot tart a nyelvhasználati minőséggel, azaz a kisgyermekkori nevelés egyik legelső alapértékével.

Nyilvánvaló, hogy azok az impulzusok és környezeti hatások, amelyek az embert életének első hat évében érik, kulcsfontosságúak az értelmi, tágabban értelmezve a szellemi fejlődésében, tudniillik a kisgyermekkor határozza meg, hogy az adott gyermekemberből később milyen felnőtt fog válni. A gyermekek társadalmi szerepvállalását, társadalmi értelemben vett emberminőségének jegyeit nagy-mértékben meghatározza, hogy milyen a család gazdasági, szociális és műveltségi helyzete. Ha ezek közül egyik feltétel sem megfelelő, előfordulhat, hogy az ilyen családok gyermekei könnyen, akaratlanul is a társadalom perifériájára szorulnak. Le kell vonnunk azt a következtetést, hogy a csa- ládi háttérnek meghatározó ereje van a gyermekek sorsára (H. Tóth, 2017a).

Általában a nehéz szociális és gazdasági helyzetű családokban, főképp a nyomorban élő családokban hiányoznak azok a pozitív ingerek, így a megfelelő higiénia: a napi fürdés, a rendszeres fogápolás, a következetes kézmosás, valamint a színes játékokkal körülvett kisgyermekkor, továbbá a nyugodt körülmények és bizony sok egyéb, amelyek a kicsinyek szellemi, értelmi és érzelmi fejlődésére jótékonyan hatnak, hathatnának. Elvárandó, hogy a kisgyermekkori társadalmi célzatú nevelés a szocializációs történésekben, változásokban, érzelmekben igen gazdag periódus legyen.

\section{Háttértudással körülvett fejlesztési lehetőségek}

Óvodapedagógusokkal folytatott szabad beszélgetésekből tudható, hogy a társadalmi környezet változásai nevelési-gondozási és oktatási problémahelyzeteket okozhatnak. Mi a tapasztalat, amikor az óvodai és a családi nevelés értékei között már-már jelentősnek nevezhető különbségek sorakoznak? Eleinte lappanganak, azonban rövidebb-hosszabb időt követôen robbannak az illető óvodapedagógusnak a növendékeivel és az azok szüleivel kapcsolatos konfliktusai. Miképpen nyílvánul ez meg elsődlegesen? A nyelvi kommunikáció és a közösségi magatartás minőségromlásában, mindenekelőtt 
- a türelmetlenségben,

- a durvaságban,

- a rendszertelenségben,

- az óvodapedagógus közösségépítő, közösségirányító szerepének el nem fogadásában,

- az esetek többségében a szülők feladattudatának gyengeségében, avagy annak hiányában, továbbá

- a konfliktusban résztvevők beszédértési és beszédfegyelmi problémáiban,

- az építő, a kreatív aktivitás és az együttmúködő érdeklődés hiányában.

Mi a legjellemzőbb különbség óvodáinkban a pedagógus-szülő viszonyban? Elsősorban és a nagyságrendekben megmutatkozó, esetleg kínosan megtapasztalható különbség a nyelvi regiszterben, a nyelvhasználatban, ugyanis a beszéd, a beszédmód, a beszédstílus közvetíti legpontosabban, a legérzékletesebben az adott család szubkultúráját, valamint az óvodapedagógus iskolai végzettségét, no meg a kommunikációban résztvevôk önigényességét is. A szóban forgó problematikus családokban az így vagy úgy alkalmazott fogalmaknak sajátos jelentéstartalmuk van, ezáltal a kisgyermekek az ezekből a családokból kikerülve nehezen értetik meg magukat az őket körülvevő külső világgal, és a legtöbb esetben az úgynevezett absztrakt gondolkodásra igen nehezen motiválhatók. Rendszeresen tapasztaljuk, hogy a problematikus családok legkülön- félébb ingerekre adott, többnyire odalökött válaszai nem reflektálók, inkább impulzívak, tegyük hozzá, hogy nem pozitív jellegükben megmutatkozóan. A sekélyes, igénytelen, nyomorúságos életvitelú családi környezetből érkező kisgyermekeknél a nyelvben, elsősorban a szókincsben és dominánsan a nyelvhasználatban tapasztalható nyelvi deficit. Ez az élethelyzet és az adott kisgyermekek életminősége által meghatározott gondolkodási stratégia az eredményes óvodapedagógusi beavatkozás, sőt segítő szándékú fejlesztés nélkül mindenképpen, hovatovább most már nyomasztóan hátránnyá válhat. Sajnos a szülői elzárkózás következtében hátránynyá is válik, és ez az iskoláztatás éveiben drámaian érezteti is a totális személyiségromboló hatását. Ferenczyné Kerekes Edit felhívta a figyelmemet arra, hogy az imént jelzett nyelvi, szókincsbéli, nyelvhasználati és a kommunikációs stratégiák vonatkozásában megmutatkozó deficitek, ignorációk a könnyűszerrel meggazdagodott, látszatokra épített, gazdag életvitelben élők bizonyos csoportjaiban ugyancsak jelenlévők. Rögzítendő a régi igazság: a gyerekszoba megléte, vagyis az intellektuálisan is jólszituált családi légkör építhet erős alapokat a kisgyermekkori nyelvi szocializáló minőségi színvonalának kialakításában. Az előzőekben fejtegetett gondolataimhoz hozzá akarom tenni az óvoda - óvodapedagógus - szülő hármas beszédstílusához, beszédmegnyilvánulásához a megszólítás eléggé zaklatott problémáját. Holott semmi szükség sincsen 
zaklatottságra, tudni illik abból kell kiindulnunk, hogy az óvodapedagógus egy települési, egy területi és az országos intézményhálózat alkalmazottja, pedagógusa, az állami és/vagy egyházi, de mindenképpen az intézményesült társadalmi normarendszer megtartásáért felelős hivatalos személyiség, ebből adódóan ne tegeződjék az óvodába, az óvodai csoportszobába érkező gyermekek szüleivel. A nyelvhasználat számos probléma forrása és gyógyírja is lehet. Mi a teljesen szükségtelen tegeződés nélkül gyógyítsunk okosan, érzékenyen a kulturált, az igényes, a tapintatos, a példaadó nyelvhasználatunkkal.

Amiként valamennyi gyakorló óvodapedagógusnak, nekem is vannak olyan példáim, amelyekkel a nyelv- és beszédminőség problémakörét tudjuk árnyaltan bemutatni, amelyek hátterében különböző nevelési stílusokat lehet felfedezni, de legelsőként is a családi nevelés viszonylatait.

Tapasztalataim szerint a testrészek, a virágos- és veteményeskertek, a színek és sok egyéb megismeréséhez, az ezekben a témakörökben tetten érhető szókincs a különböző családi hátterű gyermekeknél szokatlan mennyiségi és minőségi sivárságot, igénytelenséget, tudatlanságot, felszínességet mutat, ezért sok-sok szókincsfejlesztő, jelentésfeltáró, kommunikációs helyzetgyakorlatot követel az eredményes szókincsfejlesztés, vagyis alapos és körültekintő gyakorlásra van szükség mindenekelőtt a kisgyermekek érdekében, az ő nyelvi szocializáltságukat biztosítandó $(\mathrm{H}$. Tóth, 2016a).

Közismert nevelési, illetőleg tanítási helyzet kisgyermekkorban, hogy amikor a szülők és/vagy a testvérek öltöztetik a gyermekeiket, testvéreiket, akkor talán rendszeresen el-elhangzik az egyes ruhadarabok neve, ekképpen ezeket a kisgyermekek elsajátítják, megtanulhatják (H. Tóth, 2017b).

Ugyanakkor, ha mindez úgy zajlik, hogy az egyes ruhadarabokhoz színek, színárnyalatok is kötődnek, jelesül: „Vedd fel a sárga kabátodat, húzd fel a barna cipődet!" és még más-más információk is, például ez is elhangzik: „Azért ezeket a színeket javaslom, mert ezek a színek illenek egymáshoz, mert kellemes hangulatúak", akkor az adott kisgyermekek világlátása, szókincse, ízlése is színesedik, árnyalódik, konkrét tapasztalati élménnyel és tudással bővül, tudniillik öltözködés közben gyakorolhatják a ruhadarabok nevét, emlegethetik a színek sokféleségét, ráadásul az öltözködéssel járó cselekvés közben érzékelik még a testrészeiket is (H. Tóth, 2016b). Nem kétséges, hogy a nyelvi szocializációnak ezen a szintjén a gyermekek könnyebben azonosítják és nevezik meg, főképpen játékkal, cselekvéssel körülvéve a testrészeket, a színeket, a virágokat, a zöldségeket, a gyümölcsöket, az ízeket, az illatokat és más egyebeket, amikor is a beszéd- és kiejtésgondozó tevékenységeink folyományaként növendékeink ön- és társas-megismerési tudása, képességei eredményesebbé teszik a kisgyermekeket a tár- 
sadalomba való zökkenőmentes, sőt igen eredményes belépésre, bennmaradásra. A nyelvi különbségek más-más gondolkodási szintet jelenítenek meg. Ha az ismeretek összekapcsolódnak, illetőleg összekapcsolódhatnak, sőt tovább épülnek, akkor ezáltal új minőségeket eredményeznek.

$\mathrm{Az}$ eddigiekkel összhangban, mintegy hatásdúsítva a fent fejtegetett gondolataimat, következzék egy olyan játéktevékenység-változatokkal összekapcsolt és a versszeretetet, legkiváltképpen a magyar nyelv, ha úgy tetszik, akkor az édes anyanyelv használatát serkentő, fejlesztő, fokozó nyelv- és irodalompedagógiai ajánlás, amellyel (és hasonlókkal) időről időre megajándékozhatjuk óvodásainkat $(\mathrm{H}$. Tóth, 2020b).

Témájában kedves, zeneileg élvezetes ritmusú, vizuális megjelenésében képversnek is tekinthető a "Jön a kutya" címú Nemes Nagy Ágnes (2003) vers. Már az a gondolat, hogy képvers áll előttünk, már ez fellobbanthatja az új utakat kereső, az új megoldásoktól vissza nem rettenő óvodapedagógusok alkotókedvét akár egy úgynevezett kutyás nap megszervezésére.

Nem túlzás azt állítanunk, hogy sorsdöntő pillanatok azok, amikor a kisgyermekekkel elindulunk a versvilágok titkainak a felfedezésére, nekilátunk a versértő lét előkészítésének, óvatos, körültekintő megalapozásának. Kétségtelen, hogy jelentős szerepet játszhat ez a költemény és az ezzel a múvel való foglalatoskodásunk a versekkel való további találkozások elôkészítésében.

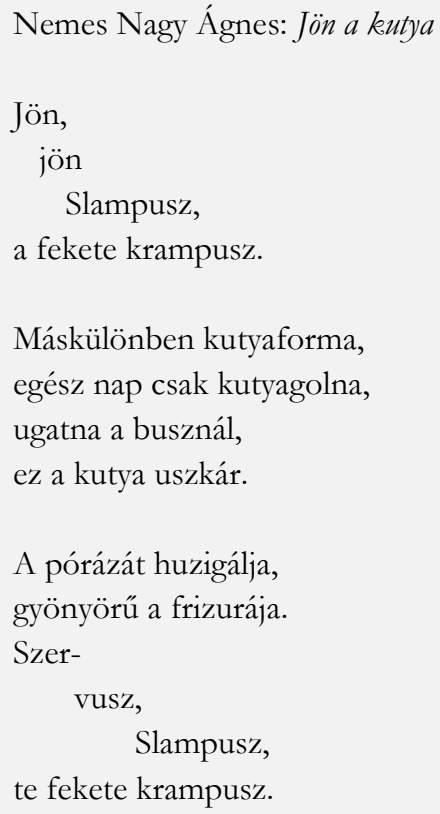

Ezzel a Nemes Nagy Ágnes-verssel is a versekkel történő játékos tevékenységek kialakításához, formálásához járulhatunk hozzá. Szépirodalmi műalkotással szembesítjük a gyerekeket, amelyik műalkotás az esztétikai megformáltsága révén hatni képes. A kialakuló versélmények erejével ez a költemény is alakítani fogja csoportszobai óvodásainkat. Nekünk, pedagógusoknak, jelen esetben óvodapedagógusoknak abból kell kiindulnunk, hogy a mûvészet hozzásegíti a gyermekeket:

- a személyesen átélt, megtapasztalt dolgokon túli emberi tudásszerzéshez,

- különböző élethelyzetek, sokféle emberi magatartás, a világ, és benne önmaguk jobb megismeréséhez. 
Az imént olvasott, pontosabban: bemutatott Jön a kutya címú játékos témájú és formájú költeménnyel való közös találkozásunk előkészítéséül kérhetjük, hogy hozzanak a gyerekek a kedvenc kutyusukról fényképet, vagy rajzolják le. Bármelyik megoldást választjuk, mindenképpen adjunk lehetőséget:

- a képek együttes megtekintésére,

- néhánynak szemléltetésre történő kiválasztására,

- faliújságunk díszítésére.

Beszélgethetünk a kutyák eredetéről, szerepéről, jelentőségéről, életmódjukról, szokásaikról is. Lehetséges, hogy olyan óvodásaink is vannak, akik tudnak, és szívesen énekelnek is kutyáról szóló dalt hallgassuk meg őket! Rendkívül jelentős érzelmi többlettel telítődhetnek azok az óvodásaink, akiknek plüssből vagy másféle textíliából készített kedvenc, szeretett, dédelgetett (esetleg: kabala-) kutyusuk van, és azt be is mutathatják csoporttársaiknak rövidebb-hosszabb történetmesélések közben. A személyességnek ez a megmutatkozása új oldalukról láttatják a kisgyermekeket, hiszen váratlan, ismeretlen dimenziókat is megnyithatnak számunkra. Ennek a költeménynek a közös megbeszélését óvodapedagógusi versmondogatással indítjuk, mégpedig úgy, hogy adjuk meg a lehetőséget a vers újra és újra történő meghallgatását követően, hogy elmondhassák a kisgyerekek: milyen kutya is jött ebben a versbéli világban? Minden bizonnyal sokféle válaszuk lesz, hallgassuk türelemmel ezeket!
Mondogassuk türelmesen a Nemes Nagy Ágnes-mûvet, mégpedig az előzô elmondásunktól eltérő megoldásban. Verselhetünk titokzatosságot vagy virgoncságot, esetleg komótosságot érzékeltető hangsúlyozással, dallamíveltetéssel. Elképzelhető az is, hogy a verskezdő mondatot enyhén szótagoló artikulálással közösen mondjuk a gyerekekkel, és a Máskülönben kutyaforma, ... sortól megint magunk folytatjuk, vagy a gyerekek folytatják az érkező újabb kutya bemutatását hangulatos, a vers iránt további érdeklődő kedvet fokozóan. Amennyiben lehetőségünk nyílik rá, akkor jelenítsük meg ezt a Nemes Nagy Ágnes-verset filctollal nagyméretű csomagolópapírra, vagy krétával táblára írva. Erre azért van szükség, hogy nyilvánvalóvá váljék a kisgyerekek számára is: ez a műalkotás képvers, a verssorok tördelése kutyust idéz a szemlélődő számára. Ha mindezt, a táblán történő megjelenítést gondosan végezzük, akkor az újabb és újabb ritmusváltó, hangerőt és hangszínezetet is váltogató versmondás közben, valamint utána is a gyerekek rajzait elhelyezhetjük a versszöveg körül. Az előző bekezdésben emlegetett tábla - mint a készség- és képességfejlesztés egyik hasznos eszköze - meghökkenést is kelthetett. Egy biztos, semmiképpen sem iskolásdit játszatunk, durvábban: erőltetünk akkor, ha nemcsak rendelkezünk kisebb méretű táblával, hanem használtatjuk is. A táblaírás, a táblára rajzolás alkalmaikor más-más térközszabályozást, más-más testtartást, ráadásul a 
függőleges helyzetű vonalvezetés másmás szemmozgást vár el. Abban teljes a szakmai-pedagógiai egyetértés (dr. Szőke Anna és Ferenczyné Kerekes Edit lektori észrevételei nyomán a magam részéről is), hogy a nagyméretű csomagolópapíron való munkálkodás: a közös rajzolás, montázsragasztás, festés, vázolás, színezés mindenképpen életszerűbb az óvodai világokban. A költemény meghallgatását, a jókedvű versmondást követő, a benyomásokról valló beszélgetés keretében szóljanak a gyerekek a mú kapcsán a vers világához illő élményeikről is. Kérdezzünk rá:

- Izgalmas-e a vers címe?

- Tetszik-e a műalkotás formája?

- Elfogadhatók-e a versszöveg köré általunk helyezett képecskék?

Folytassuk a beszélgetést:

- Vajon kiről szól ez a vers?

- Milyennek látjuk őt a szöveget hallva?

- Mit múvel a kutyus egész nap?

Bizonyára lesznek olyan kisgyerekek, akik minden reagálásuk alkalmával a saját kutyájukról is szólni akarnak, mert a valóságból indulnak ki, és ez helyénvaló, természetes élmény. Szólaltassuk meg a kevésbé izgő-mozgó gyerekeket is, vagy biztassuk őket egy-egy apró rajz elkészítésére a versbéli kutyával kapcsolatban, és ennek a rajzos vallomásnak a segítségével vonjuk be őket a Nemes Nagy Ágnes-műről formálódó beszélgetésbe. Mondjuk el ismét a verset! Most már érdemes közben ritmi- zálnunk is a rövid és a hosszú szótagokat enyhe, csendes tapsolással, esetleg a mutatóujjakkal történő, de nem erőteljes koppintással. Mivel kézenfekvő szólnunk ezekről a fogalmakról, mutassuk be három foltban, hogy hol helyezkedik el a vers címe, melyek az olvasmányt felépítő szakaszok és miképpen jelölték/jelöltük a költő nevét. Minden bizonnyal sikerül Nemes Nagy Ágnes közismert, szelíd tekintetű fényképét a gyerekek elé helyeznünk, és látva láthatják, hogy ki is varázsolta elébük Slampuszt, a fekete krampuszt. Javaslatok:

- Hozzuk szóba a krampusz fogalmát azért is, hogy tisztázzuk: ki mire gondol ennek a hangsornak a hallatán!

- Érdemes értelmeznünk a póráz jelentését is.

- Legyünk kíváncsiak arra, hogy milyennek látják a vershallgató gyerekek Slampusz gyönyörű frizuráját!

- Hogy teljessé tegyük a versbéli kutyusról való képalkotást, következhet egy jelenet hangosítása is, azaz a vállalkozók mutassák be, szerintük hogyan is ugatna a busznál ez az uszkár.

Talán nem okoz gondot lejátszanunk felvételről csoportszobánkban Bródy János, illetőleg Móricz Mihály zenéjével is, Halász Judit előadásában ezt a verset. A fejlett ritmusérzékű, jó zenei hallással rendelkező, élénk képzelőerővel bírók bizonyára mellénk szegődnek az ismétlődő versmondogatások hatására, és a Nemes 
Nagy Ágnes-versről kezdeményezett beszélgetésünket akár közös versmondással, versmondogatással is zárhatjuk.

A fentiek kapcsán önkéntelenül adódik egy kérdés: az itteni sokféle tevékenységbe integrált, a Nemes Nagy Ágnes-vers világaival foglalkozó munkálkodás nem egy rejtett műelemzési ujjgyakorlat volt?

$\mathrm{Az}$ ez idő tájt érvényes, vagy érvényesnek tekintett óvodapedagógiai módszertani szemlélet, illetőleg gyakorlat elhatárolódik az úgynevezett szemelvényelemzéstől (megjegyzés: „Az a mai gyakorlat, hogy hagyjuk érzelmileg hatni a gyerekekre az irodalmi múveket. Lényegében nem mernek a pedagógusok úgymond verset elemezni az óvodásokkal. Bár lehet, hogy ez egy külön tanulmányt is megérne. Áthidaló megoldás lehet erre is a projektmódszer, ami nem vershez kapcsolja ezeket az elemző beszélgetéseket, hanem a különböző ábrázoló-kézműves tevékenységek körében látja megvalósíthatónak" írja Ferenczyné Kerekes Edit a lektori véleményében). Biztos megvannak ennek az elhatárolódásnak a pedagógiai-pszichológiai okai, eredői. Ugyanakkor az igényesség kialakítása, erősítése, fokozása, a minőségelv érvényesítése tekintetében nem mondhatunk le az óvodáskorú kisgyermekek érzelmi-intellektuális jellemzőinek az alapozásáról - ebben egyébiránt is jelentős segítséget nyújt a szemlélődő (kontemplatív), hozzáadó (additív), haszonelvű, a hasznosságon alapuló (funkcionális) nyelv- és irodalompedagógiai stratégia (H. Tóth, 2020c). Ugye, hogy szívesen kapcsolnánk a Nemes Nagy Ágnes-verssel történő tevékenységsorozatunkhoz Weöres Sándor Kutya-tár című csodás ritmusvilágú, zeneiségű, játékos alkotását?

Elkerülhetetlen az óvodai nyelvianyanyelvi és irodalmi nevelés nézőpontjából a spontán társalgási helyzetekre való kitekintés. Az óvodás kisgyermekek az óvodai társas nevelésben sajátítják/sajátíthatják el az alapvető normakövető kiejtési, vagyis beszédhangképzési, nyelv- és ajakartikulációs szabályokat.

Ebben az életszakaszban alapozzuk/ alapozhatjuk meg a magyar beszédre alapvetően jellemző intonációs elvárásokra figyelést, azok követését, kiváltképpen a nem hadaró, nem rikoltozó beszédstílust. Ugyanakkor erősen figyeljük és pallérozzuk is az óvodáskorú kisgyermekek társasági normáknak megfelelő szókincsét. Nem tűrhetjük meg a mosdatlan szájú, arrogáns, durva, az egyénekre és a közösségre is káros, veszélyes szó- és beszédfordulatokat.

Alapvető, hogy a spontán társalgási helyzetekben is a beszéd a köznyelvi kiejtés és a kommunikáció normáinak feleljen meg. A légzéstechnikát, az artikulációt, az időtartamot, a beszédritmust, a hangsúlyt, a hanglejtést, a beszédfolyamat-váltásokat, vagyis a tempót, a hangerőt, a hangmagasságot, valamint a beszédszünet kialakításának fejlesztését spontán társalgásban folytathatjuk. Erre ad számos lehetőséget az itt következő Világgá ment a nyár címú Kányádi Sándor-mese és a Falevelek a föl- 
dön című Simon István-vers. Sose hagyjuk figyelmen kívül, hogy a spontán beszédben úgy kommunikálnak mind a gyermekek, mind a környezetükben lévők, hogy a mondatokat előzetesen nem formálják meg teljesen, hanem szakaszról szakaszra haladva improvizálnak a szituáció által megszabott keretek között. Eközben hosszabb-rövidebb szünetet tartanak/tarthatnak, mert válogatnak - nehezebben vagy magától értetődő könnyedséggel - a nyelvi és nem nyelvi elemek között. A spontán beszédben a beszélőt és a hallgatót az akusztikus kapcsolat mellett a vizuális kapcsolat is összefüzi - ez az elvárás, és ebből ne is engedjünk, azaz ne törődjünk bele abba, hogy szemkontaktus nélkülivé váljék a társalgásunk a gyermekekkel, illetőleg a gyermekek gyermekekkel zajló társalgása.

A különböző könyvek, így az úgynevezett óvodai antológiák is sokféle szövegművet kínálnak a műfajokból és műfajcsoportokból a szövegreprodukálás, a vers- és prózamondás gyakorlására. Az ezekből történő válogatás alkalmaikor legyünk gondos figyelemmel aktuális csoportunk színes, egyéni és egyénieskedő tulajdonságaira, jellemzőire is! Ugyanakkor a stílusnevelést és az óvodai nevelésben is érvényesíthető olvasásszokásfejlesz-tést is érvényesíthetjük. Az előttünk lévő Kányádi Sándor- és Simon István-szemel-vények kiválóan alkalmasak arra, hogy a felszínen túli képekre is rácsodálkozhassanak az óvodások (H. Tóth, 2015a).
Két olyan szépirodalmi szemelvénnyel gazdagíthatjuk az óvodai nyelvi-irodalompedagógiai gyakorlatunkat, amelyek már első olvasásra-hallásra is nyilvánvalóvá teszik a befogadó számára, hogy ezek a múvek az ősz világát festik meg, az ősz hangulatait idézik, az ősz ízeit varázsolják elénk. Szándékos ez a próza- és versválasztás, tudniillik fontos, hogy ne csak vers és ne csak próza jóvoltából, hanem mindkét klasszikus közlésforma segítségével, valamint a megízesített nyelv, azaz az emelkedett kifejezésmód mentén is találkozzanak óvodásaink a varázsos ősszel. Érdemes különböző napszakokra, így a kora délelőttre, azután ebéd előttire és ágyhoz kötött csendes pihenő utánra céltudatosan tervezett sétát tennünk óvodánk őszi udvari világába, majd a közeli park őszi titkai felfedezésére indulnunk. Kisebb-nagyobbacska zacskókkal, tarisznyákkal, kosárkákkal, szakajtókkal kelhetünk útra, hogy hasznos és hasznosítható kincsekkel térhessünk haza felfedezőfelderítő gyaloglásainkból. Vannak, akik azt állítják, hogy ne terheljük a kicsinyeket ilyen-olyan megfigyelési szempontokkal, hanem hagyjuk őket külső hatás nélkül, tehát ösztönösen, azaz spontán létrejövő módon rácsodálkozni az ôszi élővilágra. Az óvatos vagy inkább megfontolt óvodapedagógusok közül többek hívei adatgyűjtésre késztetni a gyerekeket óvatosan ugyan, de célzatos, apró gesztusokkal. Teszik ezt azért, hogy minél több részlete derüljön föl a világnak, amikor tanulmányozzuk a világot sok-sok játékos megol- 
dással, de sosem úgynevezett öncélú, öntetszelgő játszadozással. Tudjuk, hogy az óvodáskorú gyermekek is igénylik segítőértékelő odafigyelésünket játékcselekvéseikre, azok értékeire.

Hogy milyen míves játékokat játszhatunk az ősz arany esőjében, az itt következő Kányádi Sándor- és Simon Istvánalkotás a lehetőségek bőségét kínálja - éljünk velük! Ha tehetjük, akkor egy-egy nagyméretű csomagolópapírra írjuk fel e szemelvények szövegét, majd különböző elvarázsoló, kreatív alkotóhelyzetet teremtő játékmegoldásokkal hozzuk abba a létállapotba a gyermekeket, hogy akarják, vágyják megismerni a barnás papíron futó, gyöngyöző betűk üzenetét. Már ekkor, a két szemelvény hangulati előkészítésekor játszhatunk, játsszunk is! Mesetarisznyából, vándortarisznyából, szakajtó kukoricacsöves világából éppúgy barátságos-barátkozó játékba invitálhatjuk előre megírt csomagolólapjainkat, ahogyan a postás bácsi vagy a postás néni is elhozhatja óvodai csoportszobánkba ezeket a becses küldeményeket. És még annyiféle lehetőség kínálkozik - nemde?

\section{Kányádi Sándor: Világgá ment a nyár}

Nyugtalanul aludt az éjszaka a nagy bükkfa. Nem is aludt jóformán, csak sóhajtozott. Alig várta, hogy megvirradjon, hogy szétnézhessen a tájon. Hunyorogva nézett szembe a kelő nappal.
- Bikmakk, bikmakk! - ébredtek a mókusok is vígan ugrándozva.

Maga alá tekintett az öreg erdő. S hát mit kell látnia: csupa makk, frissen hullott bükkmakk az avar. Annak örültek úgy a mókusok.

- Bikmakk, cseremakk, mogyoró! - ujjongták a mókusok.

S az öreg erdő látta, hogy magányos társa, a tölgy is, amott a tisztáson, tanácstalanul tekint körül.

- Mi történt, szomszéd? - szólt át a bükkerdő a tölgyfának.

- Világgá ment a nyár - felelte a tölgy helyett a mogyoróbokor.

- Világgá, világgá ment - sóhajtott most már a tölgy is.

$\mathrm{S}$ már látták is mindannyian a nyár lába nyomát végig a patak mentén húzódó hosszúkás réten. Kikerics virított mindenütt a nyár nyomán. Füttyszót is hallottak. S látni vélték, mintha egy úrfi forma ugrált volna kikericsről kikericsre, de olyan könnyedén, hogy a finom szirmok meg se rezzentek alatta. Makkot, mogyorót csörgetve táncolt a falu felé.

Az ősz volt.

Bizonyára a diószüretre sietett.

Simon István: Falevelek a földön

Megrázza magát, nézd, a sok fa, hullik le a száraz levél, s mint távoli, arany vitorla, úgy lebeg, ha fújja a szél. 
Pirosan ellepi a földet, vastag, fekete sárra hullt.

$\mathrm{S}$ tőle lett már színpompás szőnyeg fasorok oldalán az út.

Szántáson magányos diófa, alatta kerek tócsa vér.

$\mathrm{S}$ a deret rózsaszínné oldja a hulló, száguldó levél.

Kopog az ősz arany esője, kalapom tetején pereg. Úszik a folyón is előre a levél, a kivénhedett.

Rázza magát, nézem, a sok fa, mintha akarva ejtené öregségét, hogy rôt vitorla vigye az enyészet felé.

De ág-karjukat égre tartják mint naphoz esdeklő kezek, kérnek vissza már, fiatalság, tavasz, virágzás, tégedet.

Sokat segít a termékeny beszélgetés indításában, ha az egyes múcímekről előzetesen, vagyis a szemelvények bemutatása, emlékezetből való felmondása elôtt már meghallgatunk felvetéseket. Lehetnek ezek értékelések, állásfoglalások arról, hogy mivel kapcsolatban üzen Kányádi Sándor bácsi és Simon István bácsi az óvodásoknak.
Személyesebbé tehetjük mindezt a teljességből, vagyis a makrokozmoszból az egyes művekhez közelítő beszélgetést. Történet ez úgy, hogy felmutatunk egyegy fényképet az alkotókról. Ilyenkor mindig akad néhány kisgyerek, aki rácsodálkozik az idegen arcokra. Előfordul, hogy ismerősnek nevezik, vagy egyszerüen szeretnének véleményt mondani felnőttekről. Mindenképpen hallgassuk meg a megszólalni kívánókat. Két dologra azonban ügyeljünk: ne legyen parttalan fecsegéssé, és semmiképpen sem kaphatnak teret bántó, illetlen megjegyzések, kifejezések. A múvel való találkozás csoportszobai megteremtésében az óvodapedagógus versmondásának lényeges, nem túlzás azt hangsúlyoznunk, hogy meghatározó szerepe van. Élnie kell korunk óvodapedagógusaiban is annak az igénynek, hogy nyomaték adandó az úgynevezett bemutató szépirodalmi szövegmondásnak. Ezzel maga a példamutatóan szájjal mesélő, költemények esetében verselő óvó néni/óvó bácsi mintegy vonzza, készteti óvodásait a szépirodalom felfedezésére.

Igen, fontos szerepe van az óvodapedagógusi bemutató szövegmondásnak. A mi tolmácsolásunkkal teremthetô meg a kapcsolat a szépirodalmi mú (a poétikai funkcióval telített alkotás) és a befogadó (itt: az óvodás kisgyermek) között. Ne kételkedjünk abban egy pillanatig sem, hogy mi a hangulatteremtő, értelmező, jól formált, a korpuszhoz illő hangvételú szövegmondásunkkal, igényesebben szólva: előadá- 
sunkkal megnyerhetjük, sőt meg is nyerjük a gyerekek figyelmét, érdeklődését az aktuális szemelvény körültekintő felfedezése iránt.

Ugyanakkor hanyag kiállással, punnyadt - (megjegyzés: a punnyadt egy életérzés és attitűd szava, egy nemkívánatos viszonyulás kifejezéséé. Olyan kellemetlen lelkiállapotot tükröz, amelyben semmi sem köti le az ember figyelmét, érdeklődését) hozzáállással csak elriaszthatjuk, sőt el is riasztjuk az óvodásokat a szépirodalom becserkészésétől. Vagyis: minden óvodapedagógusnak a bemutató szövegmondásra elő kell készülnie. Még a több évtizede pályán lévő, elismert pedagógusoknak is, mert a rutin másnapossá, önelégültté, kiégett lelkületűvé is formálhat, sôt formál.

A bemutató szövegmondásra történő előkészülés kulcsa, hogy mi magunk értsük a szemelvényt, ismerjük az adott líraiepikai alkotás jelentésrétegeit és bonyolult képi világát. Ha érti az óvodapedagógus a feldolgozásra választott, illetőleg kijelölt szépirodalmi műalkotást, hitelesebb a művel való azonosulása, a szövegtolmácsolása is. Miután világossá vált számunkra a feldolgozandó szemelvény intellektuális és emocionális vonatkozásban egyaránt, akkor meg kell határoznunk azokat az akusztikai követelményeket, amelyek figyelembevételével tolmácsoljuk a mûvet. Elsősorban a helyes, normakövető beszédfolyamat-váltásra nevelhetünk, amikor az adott szépirodalmi szemelvényt ennek a követelménynek megfelelően, ihletetten mutatjuk be a kisgyermekeknek.
Hatásos az a nyelvi-irodalom-pedagógiai felfogás, amelyik arra helyezi a hangsúlyt, hogy ismerve a lírai-epikai mú sajátosságait, a bemutató szövegmondás keretében nem dramatizálhatjuk a szemelvényeket, elsősorban a verseket nem. Helyénvaló, ha nem szoktathatjuk rá óvodásainkat egy-egy lírai mú túljátszására, dramatikus megjelenítésére, vagyis az alkotás lefestő, elmesélő, kiszínező attitűdjét érvényesítsük az előadásunkkor.

Természetesen mindannyiunknak megvannak a bevált, az eredményesség szempontjából biztosnak tűnő stratégiái a gyerekek szépirodalmi szemelvényekkel történő megkínálására. Éljünk az eredményre vezető technikáinkkal, de mindig nyitottan, az új értelmezési-feldolgozási lehetőségekre fogékonyan.

Izgalmasnak tarthatjuk az olyan játéktevékenységgel fütött szemelvénybemutatást, amikor a kisgyerekek az óvodapedagógus szövegmondása közben rajzolgathatnak, gyurmázhatnak. Az is lehetséges, hogy összerakható elemekből formákat alkothatnak. Megvalósítható, hogy a közös sétán gyűjtött levél-, kavics-, csiga-, ág-, fűszálkincsekből montázstechnikával élményvilágokat készítenek. Érdekfeszítő páros, kiscsoportos vagy a csoport egészét mozgósító játékokat szervezhetünk levélés fafajták felismerésével, megnevezésével, párosításával, lerajzolásával, kiszínezésével. Ezt lehet úgy, hogy az óvodások a világgá ment nyár utáni színpompás erdőt rajzolhatják, festhetik, avagy ragasztásos technikával helyezhetik maguk és tár- 
saik elé az ebben a játékban készített alkotásaikat, illetőleg munkáikat. Nem kevés izgalommal telített tevékenységeket szervezhetünk óvodásainkkal, amikor az erdőben és a határban élő állatokat fényképek vagy bábok segítségével mutatjuk be. Talán egyikünk sem ellenezné, sőt játszótársak is lennénk, ha azt kérnék óvodásaink, hogy játsszuk el a Kányádi Sándormesét a csoportunk vállalkozó kedvű tagjait mozgósítva.

Gondoljuk el: a mesebeli öreg erdőnek sok-sok lakója van, ahogyan a történetbéli magányos tölgyet is számos vendég kereste, keresi fel. Micsoda dramatikus játszadozás kezdődhet így! Hát még akkor, amikor a gyerekek kézmúvesalkotásait is felhasználnánk díszletezésre, kellékezésre a nyár nélkül maradt erdő megmutatása érdekében. Minden bizonnyal széles jókedvvel muzsikálnának a gyerekek alkalmi hangszereikkel, különféle témakövető hangokat adva-játszva, a világgá ment nyár utáni várakozást is érzékeltetve. Főleg akkor lesznek sikeresek ezek a tevékenységek, ha hagyományuk van az ilyen zenei játékoknak a csoportszobánkban. És közben újra és újra mesélhetnének a gyerekek a nyár tovatűnéséről, az ősz érkezéséről, a magányos tölgy gondolatairól, a pompás színekben hulló levelekrôl, a dióverésről és sok-sok egyébről, ami következik ebből a különös hangulatú, egyébként jellegzetes Kányádi Sándormúből.

Simon István Falevelek a földön című versének megtanulására, emlékezetből törté- nő rendszeres mondogatásának vágyára serkenthetjük csoportunk vállalkozó kedvű tagjait. A költeménynek nyelvi leleményekben is bő a szókincse, választékos, változatos a mondatállománya, ugyanígy hatásosak a bekezdésértékű versszakai is. Az ősz varázsát szinte ezerféle színben láttató megoldásai vannak ennek a költeménynek. Ebből adódóan a mú lendületes-mozgásos, iramtelt kifejezései magukkal ragadják, ragadhatják óvodásaink valóságlátását, élénk képzeletvilágát, alkotásvágytól fütött érdeklődésüket. Játékos, de nagyon komoly beszéd- és kiejtésgondozó eljárásainknak bővizű forrása ez a pozitív kicsengésű Simon István-alkotás.

\section{Elgondolkodtatásul}

Régi-régi tapasztalat, hogy az egyes gyermekek és a gyermekcsoportok is a legkülönféleképpen viszonyulnak az élőszóbeli meséléshez, halljuk így is: szájjal meséléshez. Újabb megfigyeléseken nyugvó tapasztalatok jelzik, hogy a kicsinyek 40-50\%-a képtelen végig figyelemmel követni a mesemondással összefüggő alkalmakat, helyváltoztatás nélkül ülve hallgatni a meséket. Ha elvonatkoztatunk olyan szempontoktól, másképpen: háttérváltozóktól, mint a mesekiválasztás, a mese előadásmódja, a tévémese romboló hatásai és még sok egyébre ezúttal nem is térek most ki, akkor lassan, de egyértelműen megállapítható, hogy az általam itt jelzett problémák szintén az elsődleges, az alapvető, az emberminőségre hosszútávon ki- 
ható nyelvi szocializációval függenek öszsze. Ne csendesüljünk annak hangoztatásában, hogy a mesélés a kisgyermekkorban rendkívül szoros anya-gyermek kapcsolatot feltételez, sőt vár el, amelyik helyzetben a mesemondás, a mesélés tevékenység hagyományosan és nem véletlenül az anyai szerepkör része (H. Tóth, 2015b). A mesélőkedvet fokozandó helyezem ide ezt a - nemrég még az aktív életpályájukat kiteljesítő - kisgyermekek nevelésével-gondozásával, nevelésével-oktatásával foglalkozó pedagógustársaim egyik kedves, motivációs bázisul is gyakran szolgáló olvasmányát, ezt a Gyulai Páltól való verses állatmesét.

Figyeljük csak, mennyi - az emberek által is megélt/megélhető - életszerű helyzet van ebben a kedves verses mesében! Nemcsak az állatszereplők közötti hasonlóságokra, egyezésekre és különbözőségekre mutathatunk rá fotók, világhálós elérhetőségek, hangfelvételek mozgósításával, hanem az emberi jellemek, tulajdonságok, cselekvések és az itteni szereplők közötti összefüggésekre is. Van már akkora élettapasztalatuk és természetmegfigyelésekből adódó tudásuk az óvodás kisgyermekeknek, hogy rá tudnak mutatni az ember és a természet kapcsolódásaira - jelen vershelyzetek ismeretében is.

Természetmegfigyelő, az élő, dinamikus természetet tanulmányozó sétáinkon megváltozik még a testtartásunk is. Másmás alakzatunk lesz, amikor a földön, a füszálakon, a földre hullott leveken izgőmozgó rovarokat lessük meg. Másképpen görnyedünk, guggolunk, egyenesedünk föl, amikor fel-felröppenő legyeket, dongókat, el-eliramodó katicákat, lepkéket, színek kavalkádjában pompázó, lombmagasságba repdeső pillangókat szemlélünk, próbálunk a tekintetünkkel befogni. Ilyenkor a szemmozgásunk is izgatottabb, a fejtartásunk sem merev, hanem eseménykövetőn ruganyosabb mozgású. Hát még, amikor a lombok között élő állatokra vetjük kíváncsi tekintetünket, kiváltképpen akkor leszünk valósággal csapongó mozgásúak, amikor a lombkorona fölé röppenő, emelkedő szárnyasokat iparkodunk megfigyelni.

Kétségtelen, hogy ezekre a sétákra, a megfigyelésekre a mozgásfajták számossága, különlegességei miatt is készülnünk kell, hiszen a fekvőtől a guggolón át a felfelugráló testtartásokig annyiféle változat fordulhat elő, valljuk be: fordul is elő. Ezért beszélgetnünk kell ezekről a mozgásfajtákról, az önmagunkat és a társainkat védő, tiszteletben tartó térközszabályozásokról - feltétlenül érdemes efféle játékokat is játszanunk csoportszobáink nyugalmában, a sétáink élményeire készülődve.

Mindenképpen szóra érdemes a ruházatunk, a kezünk, főképpen a szemünk védelme - ezeknek is ott kell lenniük az egészséges életre nevelés lehetőségei között, amiként a nyelvhasználat fejlesztésének, a szókincs gyarapításának is.

Településeink parkjaiban minden bizonnyal könnyűszerrel fedezhetjük fel óvodásainkkal közösen a természetmeg- 
figyelő sétáink közben a jellegzetes tollazat színű: galambszürke, kecses testalkatú (feltűnően hajlékony, oda-odabújós), búgó hangú vadgalambokat. Mindig párban tollászkodnak, közös erőfeszítéssel építgetik az egyébként meglehetősen szerény kivitelezésű fészküket.

Gyulai Pál: $A$ squarka és a gilice

Egyszer a szarkához

Gilice betoppan:

„Taníts, hogy kell fészket rakni,

Te tudod legjobban.”

„Szívesen, húgocskám!”

Dolgozik már rajta.

„Csak így, csak úgy, csak, csak, csak!”

Mindegyre azt hajtja.

Szótlanul ott ülni

Gilice is restell.

Búgó hangján: „'Túdom, túdom,”

Beszélgetni kezd el.

„Hát csináld, ha tudod!”

Szarka mond haraggal,

Félbe-szerbe hagyja dolgát,

S elröpül azonnal.

Szarkáéhoz képest,

Fészke gilicének

Ezért maradt csak egy darab -

Eddig tart az ének.
Ezek a séták és megfigyelések szinte kínálják azokat a nevelési-gondozási és ne restelljük kijelenteni: tanulási alkalmakat, amelyek kamatoztatásával a környezetükre, az élővilágra, az embert körülvevő természetre érzékenyebbé növeszthetjük 3-6/7 éves növendékeinket. Mire gondolhatunk? Effélékre például:

- a vadgalambok testét borító tollazat színe, formája;

- a vadgalambok röppenése, leszállása;

- a vadgalambok hangszínezete, beszédmódja;

- a vadgalambfészkek külleme, anyaga és így tovább.

Pazar ismereterősítő, tudásgyarapító minden parkbéli sétánk, hiszen ezek a természet világában való megmártózásunk alkalmai. Feltétlenül hasznos a vadgalambok meglesése, sőt megfigyelése előtt a világháló és természetismereti albumaink segítségével szembesülnünk a szarka testi jellemzőivel és a szarkafészek minőségével. Efféle tudáselemek, megfigyeléskincsek birtokában még nyitottabbak, még szemlélődőbbek, még tudatosabban vizsgálódók lesznek óvodásaink. A vadgalambok tanulmányozása alapján szóba kerülnek olyan fogalmak, mint a fej, a szem, a csőr, a nyak, a hát, a toll/tollazat, a szárny, a begy, a láb, a karmok. Rögvest összehasonlíthatjuk tapasztalatainkat a szarkáról szerzett ismereteinkkel, majd magunkra nézve máris a madár és az ember közötti különbségekre, hasonlóságok- 
ra, egyezésekre összpontosíthatunk. Az iménti szükséges szókincs mellé odasorakoztathatjuk még a fészekrakó, tojásköltő pompás hangzásvilágú magyar szavainkat. És megint felidézhetik óvodásaink a maguk élményvilágát, családismeretét, hiszen apa és anya is fészekrakó, amikor gondoskodnak a család nyugalmáról, életéről, békés környezetéről. Az így, vagyis a galambokkal összefüggő megfigyeléseink hasznos ismereteit lelkesen mozgósítják majd a kisgyermekek, amikor a házkörüli állatokról gyűjtünk tapasztalatokat. Már kéthárom sétát követően, illetőleg parkbéli játékaink közben is átlényegülhetünk, és örvendezve, ügyeskedve

- utánozhatjuk a vadgalambokat;

- el-eljátszhatjuk a vadgalambokkal kapcsolatos cselekvéseket;

- anyagféleségeket gyüjthetünk vadgalambfészek építéséhez;

- megpróbálhatjuk a vadgalambfészek építését földön, padon, vagy valamelyik, például a síkból kiemelkedő játékunkon;

- dramatizálhatjuk ezt a Gyulai Pálverses mesét.

A dramatizálással összefüggésben, a szarkáról és a gilicéről szóló verses állatmese dramatikus előadására készülődve igazán kiváló szerepjátékokra, kommunikációs helyzetgyakorlatokra nyílik számos alkalmunk. Milyen felfogásban, miféle közlésmódban nyilvánulhat meg a mesélő, illetőleg mutatkozhatnak meg a mesélők?

Lehet a mesélő kedveskedo, gunyoros, szigorú, humoros, magyarázó, fennhéjázó és még sokféle. Ezeket a megoldásokat az odaillő, adekvát emberi gesztusokkal kapcsolhatjuk össze. Mindeközben figyelhetünk a hang-színezetváltásokra, a beszédtempóval való játszadozásokra, a gesztusnyelv alkalmazására is.

A megfelelő jellemmegmutató eszközkészlet összeválogatásakor udvarias, illendő, figyelmes és mindenképpen tanulságos beszélgetéseket kezdeményezhetünk, illetőleg irányíthatunk - ismét hagyjuk a kisgyermekeket kibontakozni, hogy a tapasztalati világukból minél több elemet mozgósíthassanak. És van még valami itt, a meséléssel összefüggésben

Nyilvánvalóan és joggal történik, hogy felötlik bennünk ez a kérdés: hogyan is mesél anya és apa esténként és egyáltalán? Az sem kizárható, hogy a kisgyermekek vetik fel, hogy szeretnék elmesélni, miképpen is mesélnek nekik a szüleik, a nagyszüleik.

Óvatosnak, tapintatosnak és rendkívül körültekintőnek kell lennünk, mert az ilyen helyzetek igen bonyolult kérdéseket gerjeszthetnek, alkalmanként problémákat is felszínre hozhatnak. Vagyis: ismét és ismét a gyermekek érdekeit szem előtt tartó pedagógiai tapintatunkat kell érvényesítenünk.

\section{Összefoglalásul}

Jelen tanulmányban mindenekelőtt az óvodapedagógusokra fókuszálva foglalkoztunk a beszédműveltség körébe is tartozó nem kevés szakmai-pedagógiai, va- 
lamint etikai kérdéssel. A fentiek nyomán is, és a kisgyermekekkel foglalkozó szakemberek iránti szakmai elvárásokra tekintettel is megalapozottan válaszolhatunk a címbeli kérdésre határozottan: igen, elvárt követelmény az óvodapedagógusoktól és minden pedagógustól a beszédműveltség. A nevelési-gondozási és a nevelésioktatási helyzetekben megmutatkozó legkülönfélébb, a nyelvi nevelőmunkánkkal kapcsolatos problémák csökkentési lehetőségeit latolgatva az alábbiakat állítom, állíthatom magunk elé a sikeres, de legalábbis a nem eredménytelen személyiségfejlesztő nyelvi szocializáció, a beszédmüveltség sikeres gondozása érdekében:

1) Megkerülhetetlenül fontos, hogy az egyes óvodai intézmények, összességében az óvodai intézményhálózat következetesen, mindenképpen a felnövekvő gyermekekre, az ő létérdekükre feltétlenül hatva egészítse ki a családi nevelési szokásokat. Ebben az egyáltalán nem könnyü tevékenységfolyamban az első és legfontosabb tennivalónk a beszéd- és nyelvhasználatbéli különbözőségek közelítése, majd a minőségi beszédszint, a verbális kommunikáció fejlesztése (H. Tóth, 2015c).

2) Az óvodáskorúaknál fokozott figyelemmel kell lennünk a példamutató beszédlégzésre, artikulációra, beszédtempóra, hangoztatásra, kapcsolva ezekhez például a tárgyak, a személyek, a színek, a jelenségek és más-más dolgok megnevezéssel, játéktevékenységbe integrált alkalmazásával történő beemelését, majd következetes használatát a mindennapokban, tekintettel az ilyenfajta szókincsbővítésre (Körmöci, 2015).

3) Mivel rendkívül durva mértékűvé lett az elnagyolt, elhadart, elkapkodott, gyengén artikulált beszéd, és ennek a hallás utáni észlelése komoly nehézségekkel jár, mindenképpen figyelemmel kell lenniük az óvodapedagógusoknak és a szülőknek is a maguk beszéd- és kiejtésigényességére, a kicsinyek hallással összefüggô memóriájának a fejlesztésére.

4) Feltétlenül szükséges az olyan beszédhelyzetek megteremtése, ahol megélhetik már az óvodás gyermekek is a nyelv szépségét, a beszéd örömét; erre a legkézenfekvőbb, legtermészetesebb a saját élmények elmondása, az önálló történetalkotások, a részben irányított és/vagy önálló képszemlélés keretében zajló, úgynevezett képolvasások, amelyek szintén kínálják a szövegezés lehetőségét. A beszédhelyzetek teremtésében hangsúlyosnak tartom a kisgyermekek által hozott élmények elmondására késztetést olyan kérdésekkel, amelyek kifejtésre, mesélésre, elmondásra bátorítóak. Ennek jó talaja lehet az úgynevezett beszélgetőkör, amikor a gyerekek adott vagy választott témákról fejtik ki gondolataikat, vagy elmesélik társaiknak, hogy mi történt velük hétvégén (H. Tóth, 2020b). A beszédgátoltság, a beszédcsendesség oldására, de a hadaró, a légszomjas, az artikulációs problémákat mutató beszéd figyelmes, türelmes, tapintatos kezelésére kiválóan alkalmasak a mesealkotások, avagy a mesebefejezések konstruálása is lehet beszédre 
késztetés, amiként a mese- és versmondások, a mese- és versdramatizálások mellett a változatos technikájú bábozások, a bábjátékok szorgalmazása elengedhetetlen $(\mathrm{H}$. Tóth, 2015d).

5) És végül: ne legyünk restek érdeklődő figyelmünket az osztrák polihisztor és filozófus, Rudolf Steinernek a munkásságából vett eme gondolatára vetni. Fontoljuk meg és alkalmazzuk emberminőségünkért: „Aki igazat beszél, elősegíti az emberiség fejlődését, aki hazudik, akadályozza azt."

\section{Irodalom}

Gyulai Pál (é.n): A squarka és a gilice. Letöltés: 2020.04.16 Web: https://www. facebook.com/KedvencekversekIdeze tekEsEgyebSzepsegek/posts/1121439 111241195/

H. Tóth István (2015a): Míves játékok az ősz arany esőjében. Óvodai Nevelés, 9: 2-5.

H. Tóth István (2015b): Kicsit másképpen a mesék világáról. Óvodai Nevelés, 6: 10-13.

H. Tóth István (2015c): Sqóra készteto" (Hattérismeretek, fejlesztési lehetöségek óvodáskoriak beszéd-és kiejtésgondozásához). Flaccus Kiadó, Budapest. 12-21., 134 138.

H. Tóth István (2015d): Beszélni: helyesen, pontosan, érthetően, választékosan - csak így érdemes. Óvodai Nevelés, 10: 20-21.

H. Tóth István (2016a): Tulipán, szegfü, szarkaláb, zsálya és társai - Válogatás a virágismeret szókincséből. Óvodai Nevelés, 9: 28-30.

H. Tóth István (2016b): Sưrű erdő, kopasz mező és társai - Válogatás a testismeret szókincséből. Óvodai Nevelés, 2016. 8: 18-20.

H. Tóth István (2017a): A játék és a felelősség az óvodai és a kisiskoláskori pedagógiai gyakorlatban. In Fehér Ágota, Mészáros László (szerk.): „... Et vocavit vocatione sua sancta" - $A$ pedagógiai hivatás a keresztény nevelésben. Apor Vilmos Katolikus Főiskola, Vác. 133146. p. Ugyanez megjelent: Katolikus Pedagógia, Vác-Budapest. 2017. 1-2: 11-24.

H. Tóth István (2017b): Memorizálhat-e óvodáskorú gyermek. Óvodai Nevelés, 5: 30-32.

H. Tóth István (2020a): Tünödés a kisgyermekkori nevelés és a nyelvi szocializáció kapcsolatáról. Letöltés: 2020.03.30. Web: https://enyelvmagazin.hu/2020/03/2 9/tunodes/

H. Tóth István (2020b): Kutya egy világ! Óvodai Nevelés, 1: 8-10.

H. Tóth István (2020c): Értékkeresés az óvodai magyar nyelvi nevelésért a hagyományápolás tükrében (Szemlélódés - hozzáadás hasznosság). Sprint Kft. Kiadó, Budapest. 8-11.

H. Tóth István (2020d): Értékkeresés az óvodai magyar nyelvi nevelésért a hagyományápolás tükrében (Szemlélódés - bozzáadás hasznosság). Sprint Kft. Kiadó, Budapest. 13-19.

Kányádi Sándor (s.a.). Világgá ment a nyár. Letöltés: 2020.04.16 Web: https:// 
www.3szek.ro/load/cikk/43876/kany adi_sandor:_vilagga_ment_a_nyar Körmöci Katalin (2015): A tevékenységbe integrált tapasztalatszerzés gyakorlatáról. Óvodai Nevelés, 3: 13.
Simon István (é.n.). Falevelek a földön Letöltés: 2020.04.16 Web: http://sysyaranylsz.blogspot.com/2012/07/simo n-istvan-falevelek-foldon.html 